\title{
Conversion of Bio-ethanol over Zeolites and Oxide Catalysts
}

\author{
K. Dossumov, D. Kh. Churina, G. Y. Yergaziyeva, M. M. Telbayeva, and S. Zh. Tayrabekova
}

\begin{abstract}
The zeolites and oxide catalysts are investigated in the conversion of bio-ethanol. It is shown that the formation of the products depends on the feedstock composition and the composition of the reaction mixture. It is determined that at the conversion of bio-ethanol over the zeolites $3 \mathrm{~A}, 4 \mathrm{~A}, 5 \mathrm{~A}$, and $13 \mathrm{X}$ products of cracking, reforming, dehydration and oligomerization of ethylene are formed. The cerium-containing catalysts are studied via electron microscopy and temperature programmed desorption of ammonia. Doping $\mathrm{Ce} / \gamma-\mathrm{Al}_{2} \mathrm{O}_{3}$ catalyst with lanthanum is shown to increase its dispersion and the number of active acid sites, thereby improving its activity.
\end{abstract}

Index Terms-Bio-ethanol, zeolite, cerium-containing catalyst, aromatic hydrocarbons, ethylene, conversion.

\section{INTRODUCTION}

The steady rise in prices for petroleum feedstock in the world, which is observed in the last few years, leading to higher prices for basic petroleum products. Currently under active search for new basic raw materials that can replace oil as a fuel in the production and in the chemical industry [1]-[5] Typically alternatively treated natural gas or coal, but they, like oil, are non-renewable energy sources. Furthermore, there is an environmental problem - pollution of the atmosphere with carbon dioxide, since any organic substance is transformed into it by incineration, which leads to an increase in its content in the atmosphere.

One of the possible substitutes for oil, bioethanol is produced by processing biomass [6]-[8]. This route is often regarded as the most realistic way to reduce $\mathrm{CO}_{2}$ emissions into the atmosphere. The use of bioethanol in fuel purposes is largely limited, mainly due to its high hygroscopicity and possible freezing of dissolved water at low temperatures in cold regions. In northern countries the ethanol is mixed with fuel and is used as an additive to gasolines (5-15\%). Currently considered a promising further processing of ethanol in organic substances and their mixtures having higher fuel characteristics, such as energy intensity, low corrosivity, vapor pressure, etc. Thus, the increased degree of correspondence produced biofuels makes real oil

Manuscript received April 11, 2015; revised June 17, 2015. This manuscript was supported in part by Ministry of Education and Science of the Republic of Kazakhstan.

Dossumov K. and Churina D. are with Center of Physical-chemical Methods of Investigations and Analysis of al-Farabi Kazakh National University, Almaty, Kazakhstan (e-mail: dossumov50@mail.ru; dina.churina@gmail.com).

Yergaziyeva G. and Telbayeva M. M. are with Institute of Combustion Problems MES RK, Almaty, Kazakhstan (e-mail: ergazievag@mail.ru; telbaeva.moldir@yandex.kz).

Tayrabekova S. is with al-Farabi Kazakh National University, Almaty, Kazakhstan (e-mail: samal_tayrabekova@mail.ru). consumption and, consequently, its competitiveness in world markets. Most of the projects for the processing of ethanol do not yet have an industrial implementation, but research in this direction are under way as to obtain a semi-synthetic oil, and for the production of clean fuels [9]-[12].

The most environmentally friendly fuel is now considered a hydrogen. However, the use of hydrogen as a fuel in internal combustion engines is currently difficult because, firstly, there are considerable difficulties in storing sufficient amounts of hydrogen gas on board a vehicle, and secondly, the combustion temperature of hydrogen in air is $3000^{\circ} \mathrm{C}$, which in its turn, imposes restrictions on the materials of the engine, and also leads to oxidation of nitrogen in the air to form toxic oxides of nitrogen [13]-[16]. The most promising is the consideration of bioethanol as a raw material for the components of motor fuels, olefins (mainly ethylene), and aromatic hydrocarbons.

Olefins are widely used in industry [17], [18]. Due to the presence of double bond the olefins are reactive which makes them the many important product in the various processes of organic chemistry. For example, ethylene is the most demanded intermediate chemicals. Petrochemical potential of individual countries is assessed in terms of production of lower olefins - ethylene and propylene, which are the basic chemical raw materials for the production of polyethylene, polypropylene, plastics, styrene and other products. According to forecasts of Nexant Inc. consultancy world consumption of ethylene in the next 10 years will increase from 100 million tons to 160 million tons per year.Demand for polyethylene will increase from 60 million tons to 100 million tons, and for polypropylene - from 40 million tons to 60 million tons a year.

The pyrolysis of straight run gasoline and liquefied petroleum gas is the method most commonly used for the synthesis of ethylene. However, this process is exothermic and requires high reaction temperatures $\left(780-1200^{\circ} \mathrm{C}\right)$ and the use of steam as a heat transfer agent at a ratio of 1: 1 . Estimates of industrial emissions show [19] that the production of ethylene by such technology releases great amounts of carbon dioxide into the atmosphere. For ecological and economic reasons, it is better to use $\mathrm{C}_{1}-\mathrm{C}_{4}$ alcohols as an initial feedstock for the production of olefins. The production of olefins is of practical interest, as they are widely used in the industrial synthesis of polymers and a variety of other valuable products of organic chemistry, due to their high reactivity [20], [21].

\section{EXPERIMENTAL}

Catalytic conversion of bioethanol was studied in this work. 
The studies were carryed out on the automatically catalytic flow installation (Fig. 1). The reactor was a metal tube of 40 $\mathrm{cm}$ in length, and its internal diameter was $12-15 \mathrm{~mm}$. During the experiments the reactor was vertically placed in an electric furnace. The reaction mixture was fed to the reactor bottom. The mixture passes between the outer tube of the reactor and the container with the catalyst and go out down. Control of the composition and the expense of initial reacting mixtures, regulation of temperatures in the reactor, evaporator, and start of analysis were carried out using the software.

The gaseous reaction products (hydrogen, ethylene etc.) were analyzed on chromatograph (HROMOS GH-1000).

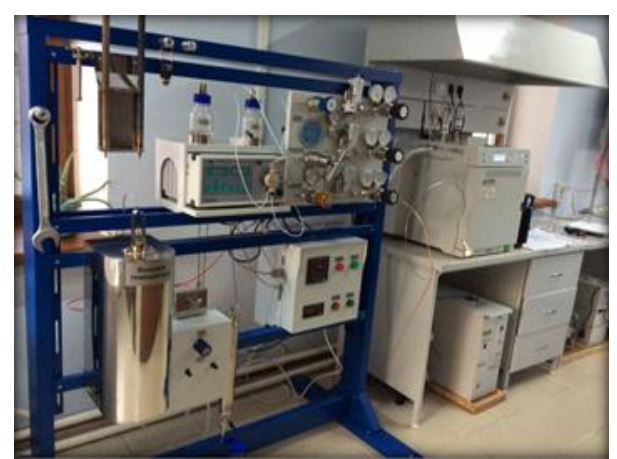

Fig. 1. Flow catalytic setup.

\section{RESULTS AND DISCUSSION}

In this paper we tried to evaluate the possibility of producing ethylene and aromatic hydrocarbons from bioethanol. As the initial reactants was chosen bioethanol with different composition. Bioethanol 1 (95\% ethyl alcohol, $5 \%$ water) and bioethanol 2 having the following composition - ethyl alcohol (92\%) of tert-butilcarbinol (5.6\%), cyclohexane $(0.64 \%)$, acetal $(0.61 \%)$, isopropyl alcohol $(0.47 \%)$, toluene $(0.39 \%)$. As catalysts of the process have been studied zeolites - 3A, 4A, 5A and $13 \mathrm{X}$. The experiments on the influence of the nature of the carrier on the of the products yield have been studied as a flow of inert gas and without it. As the inert gas was selected argon (Ar). Fig. 2 shows the influence of the nature of the carrier and argon in the reaction mixture under at a reaction temperature of $350^{\circ}$ C.

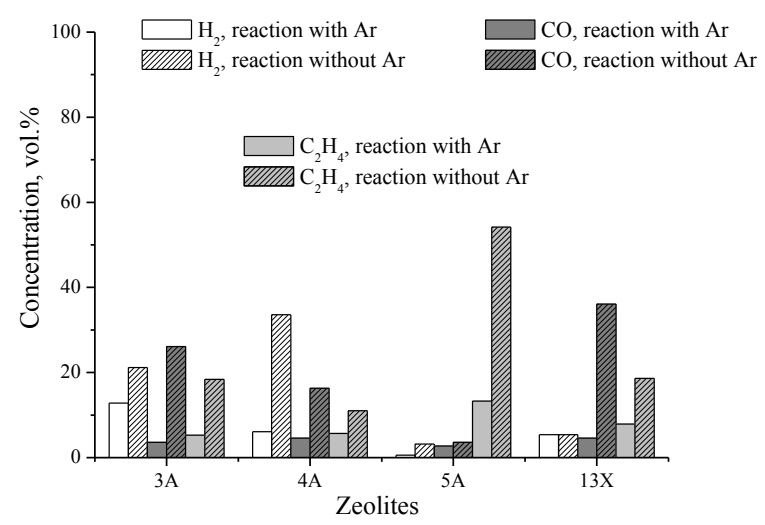

Fig. 2. Influence of the nature of carriers and argon in the reaction mixture on the yield of products of bioethanol 1 conversion.

Fig. 2 shows that at the conversion of ethanol in a stream of inert gas over the 3A zeolite produces about 12 vol.\% hydrogen and small amount of carbon monoxide and ethylene.
The same results are typical of other zeolites. At the conversion of ethanol without adding an inert gas into the reaction mixture increases the yield of products. Over the zeolite $3 \mathrm{~A}$ is formed synthesis gas with a ratio of $\mathrm{H}_{2}: \mathrm{CO}=1$ : 1.2 and ethylene with a concentration of $18.3 \mathrm{vol} . \%$. Zeolite $4 \mathrm{~A}$ runs in the direction of the formation of hydrogen, wherein the hydrogen concentration in the reaction product reaches a value of $33 \mathrm{vol} . \%$. The highest yield of ethylene (54 vol.\%) is formed over the $5 \mathrm{~A}$ zeolite. Over the $13 \mathrm{X}$ zeolite a substantial amount of carbon monoxide (36 vol.\%) is formed, also in the reaction products are observed of $\mathrm{H}_{2}(5.4$ vol.\%) and ethylene (18.6 vol.\%). It should be noted that at conversion of $95 \%$ ethyl alcohol over these zeolites liquid hydrocarbons are not formed.

These results demonstrate that, when used bioethanol 2 as feedstock special changes in the composition of gaseous products is not observed (Fig. 3).

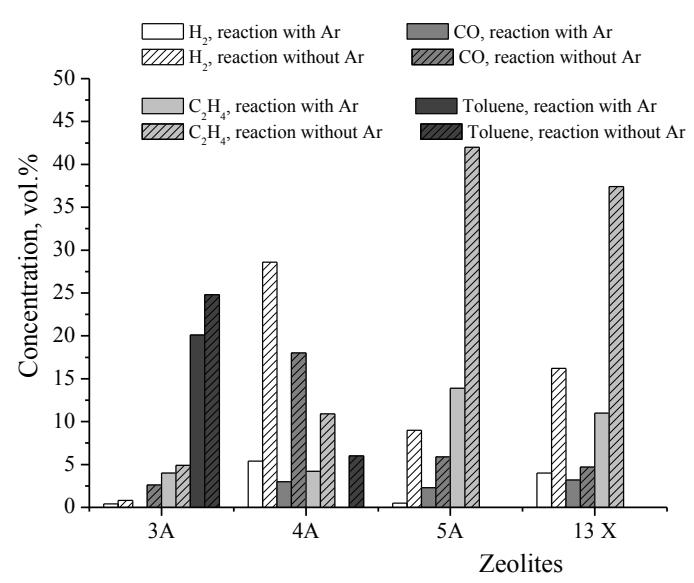

Fig. 3. Effect of the carriers nature and argon in the reaction mixture on the yield of products of bioethanol 2 conversion.

Also active on the yield of ethylene is carrier $5 \mathrm{~A}$, the ethylene concentration in the reaction products up to 42 vol.\%. Over the $4 \mathrm{~A}$ carrier is formed the synthesis gas with a ratio of $\mathrm{H}_{2}: \mathrm{CO}=1.5: 1$, wherein the hydrogen concentration is 28 vol. \% and $\mathrm{CO}-18$ vol. \%.

In the conversion of bioethanol 2 over the zeolite $3 \mathrm{~A}$ liquid reaction products contain toluene. In the study of the conversion of ethanol in the inert gas flow is formed about 20 vol.\% toluene, conducting the reaction without addition of argon to the reaction mixture leads to increase of the concentration of toluene to $24 \mathrm{vol} . \%$. Besides toluene liquid reaction products formed in trace amounts of benzene. About $5 \mathrm{vol} . \%$ of toluene formed over the zeolite 4A. Over the other zeolites (5A and 13X), liquid hydrocarbons are not formed.

At a conversion of bioethanol 1 and bioethanol 2 in gaseous reaction products over the all zeolites formed as methane and carbon dioxide. The concentration of methane increases when used as the feedstock of bioethanol 1, also in the absence of inert gas in the reaction mixture.

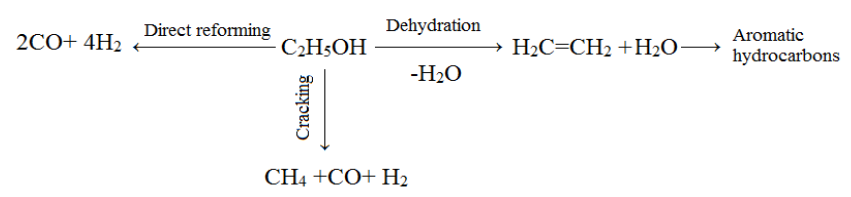

Fig. 4. The scheme of ethanol conversion over zeolites. 
According to the results it can be assumed that over the investigated zeolites several reactions have places as dehydration reaction, cracking, reforming of ethanol, and ethylene oligomerization (Fig. 4).

Further the activity of Ce-containing catalysts were studied in the dehydration of bioethanol 1 . The catalysts were prepared via incipient wetness impregnation of the support, followed by drying at room temperature and $300^{\circ} \mathrm{C}$, with subsequent calcination at $500^{\circ} \mathrm{C}$ for $3 \mathrm{~h}$. The catalytic activity of the catalysts was studied in the $250-450^{\circ} \mathrm{C}$ range of temperatures with hourly space velocities (HSVs) of 1500-13000 $\mathrm{h}^{-1}$. Before each experiment, the catalysts were reduced in a hydrogen flow for $1 \mathrm{~h}$ at $500^{\circ} \mathrm{C}$ and atmospheric pressure.

Data on the effect the reaction temperature has on the activity of $\mathrm{Ce} / \gamma-\mathrm{Al}_{2} \mathrm{O}_{3}$ catalyst at $\mathrm{HSV}=3000 \mathrm{~h}^{-1}$ are given in Table I. It can be seen that ethylene is formed at a reaction temperature of $250^{\circ} \mathrm{C}$ with a concentration of $39 \mathrm{vol} . \%$ and an ethanol conversion of $42 \%$. As the reaction temperature grows, ethanol conversion rises to $59 \%$, and the concentration of ethylene, a key product, reaches 56 vol. $\%$. In addition to ethylene, propylene $(0.70 \mathrm{vol} \%)$ also appears among the reaction products. As the reaction temperature rises to $350^{\circ} \mathrm{C}$, the ethylene concentration reaches $67 \%$.

TABLE I: EFFECT THE REACTION TEMPERATURE ON THE CONCENTRATION OF PROducts ON CE- $\mathrm{AL}_{2} \mathrm{O}_{3}$ CATALYST

\begin{tabular}{cccccc}
\hline \hline $\mathrm{T}^{\circ} \mathrm{C}$ & $\mathrm{K}_{\mathrm{EtOH}}, \%$ & $\mathrm{CH}_{4}$ & $\mathrm{C}_{2} \mathrm{H}_{4}$ & $\mathrm{C}_{2} \mathrm{H}_{6}$ & $\mathrm{C}_{3} \mathrm{H}_{6}$ \\
\hline 250 & 42 & - & 39 & - & - \\
300 & 59 & - & 56 & - & 0.70 \\
350 & 75 & - & 67 & - & 4.5 \\
400 & 87 & - & 80 & 0.38 & 3.8 \\
450 & 90 & 1.0 & 75 & 0.62 & 3.3 \\
\hline \hline
\end{tabular}

The highest concentration of ethylene $(80$ vol.\%) is observed at a reaction temperature of $400^{\circ} \mathrm{C}$, at which the ethanol conversion of $87 \%$. At temperatures of $400^{\circ} \mathrm{C}$ and higher, ethane is formed in small amounts $(0.38 \mathrm{vol} . \%)$, in addition to ethylene and propylene. Raising the reaction temperature to $450^{\circ} \mathrm{C}$ lowers the target product yield to 75 vol. $\%$ at an ethanol conversion of $90 \%$. Our data show that the best temperature for the dehydration of ethanol on $\mathrm{Ce} / \gamma-\mathrm{Al}_{2} \mathrm{O}_{3}$ catalyst is $400^{\circ} \mathrm{C}$. The effect of lanthanum doping on the activity of the $\mathrm{Ce} / \gamma-\mathrm{Al}_{2} \mathrm{O}_{3}$ catalysts was studied in the $250-450^{\circ} \mathrm{C}$ range of temperatures at HSVs of $1500-13500$ $\mathrm{h}^{-1}$ (Fig. 5). As can be seen from Fig. 5, the hourly space velocity has a slight effect on the activity of the catalyst at reaction temperatures of 250 and $300^{\circ} \mathrm{C}$, and the key product (ethylene) yield is nearly the same $(\sim 20 \%)$ at all HSVs. When the reaction temperature rises to $350^{\circ} \mathrm{C}$, the optimum concentration of ethylene $(62 \mathrm{vol} . \%)$ is observed at $W=$ $13500 \mathrm{~h}^{-1}$.

After doping the $\mathrm{Ce} / \gamma-\mathrm{Al}_{2} \mathrm{O}_{3}$ catalyst with lanthanum at a reaction temperature of $400^{\circ} \mathrm{C}$, the optimal $\mathrm{HSV}$ shifted toward higher values (3000 to $6000 \mathrm{~h}^{-1}$ ), at which the maximum ethylene concentration of 82 vol.\% is observed.

Effect of lanthanum concentration in the structure $\mathrm{CeLa} / \mathrm{\gamma}_{2} \mathrm{O}_{3}$ catalyst was studied in the $1-3$ mass.\% range
(Fig. 6). At temperature $350^{\circ} \mathrm{C}$, the active catalyst is $3 \% \mathrm{Ce}+$ $1 \% \mathrm{La} / \gamma-\mathrm{Al}_{2} \mathrm{O}_{3}$. As the reaction temperature rises to $400^{\circ} \mathrm{C}$, higher concentration of ethylene observed over $3 \% \mathrm{Ce}+3 \%$ $\mathrm{La} / \gamma-\mathrm{Al}_{2} \mathrm{O}_{3}$ catalyst.

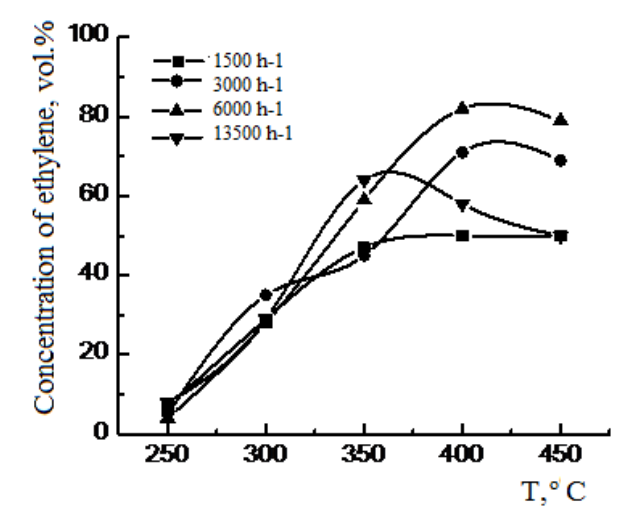

Fig. 5. Effect of reaction temperature and hourly space velocity on the yield of ethylene on $\mathrm{CeLa} / \gamma-\mathrm{Al}_{2} \mathrm{O}_{3}$ catalyst.

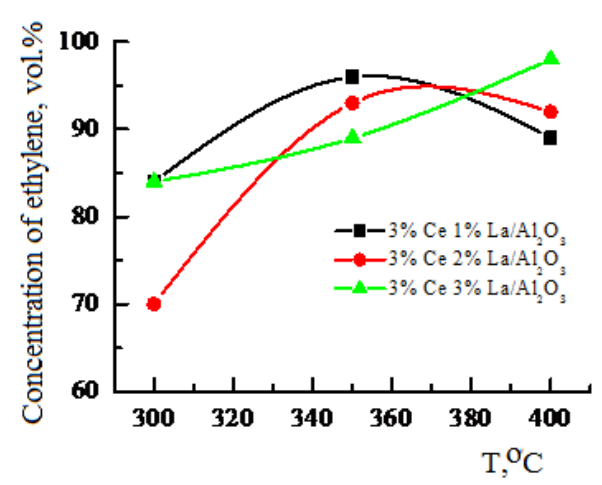

Fig. 6. Effect of ratio Ce:La on the catalysts activity.

The textural characteristics of catalysts were determined by BET method. Getting results are shown in Table II. An increase of calcination temperature from 200 to $400{ }^{\circ} \mathrm{C}$ greatly reduces the specific surface area of catalyst from 162 to $69 \mathrm{~m}^{2} / \mathrm{g}$. The increase of calcination temperature to $500{ }^{\circ} \mathrm{C}$ enhances surface area of catalyst to $133 \mathrm{~m}^{2} / \mathrm{g}$ by stabilizing of the catalyst composition.

The study of surface area of catalysts with different concentration of lanthanum showed, that for $3 \% \mathrm{Ce}+3 \% \mathrm{La} /$ ${ }_{8} \mathrm{Al}_{2} \mathrm{O}_{3}$ catalyst observed highest values of surface area and pore volume: $S$ surface area $=174 \mathrm{~m}^{2} / \mathrm{g}$, Vpore $=0.075 \mathrm{~cm}^{3} / \mathrm{g}$. The catalyst showed the highest catalytic activity in the reaction to produce ethylene from ethanol at a reaction temperature of $400^{\circ} \mathrm{C}$.

The phase composition of the catalysts was determined via electron microscopy. The results from studying the $\mathrm{Ce} / \gamma-\mathrm{Al}_{2} \mathrm{O}_{3}$ catalyst are shown in Fig. 7 . It can be seen that there was an agglomeration of 5-10 nm particles whose X-ray microdiffraction picture can be attributed to a mixture of phases $\mathrm{Ce}_{6} \mathrm{O}_{4}$ (JCPDS, 32-196) and $\mathrm{AlCe}_{3}$ (JCPDS, 9-260). Doping $\mathrm{Ce} / \gamma-\mathrm{Al}_{2} \mathrm{O}_{3}$ with lanthanum increases the dispersion of the catalyst (Fig. 8, but some aggregates of fine $(2 \mathrm{~nm})$ particles are observed in the aggregates, along with particles $10 \mathrm{~nm}$ in size. The X-ray microdiffraction picture shows a small set of rings and can be attributed to a mixture of phases $\alpha$-La (JCPDS, 2-618), $\mathrm{Ce}_{2} \mathrm{O}_{3}$ (JCPDS, 23_1048), $\mathrm{La}_{2} \mathrm{O}_{3}$ (JCPDS, 22-269), $\mathrm{La}_{2} \mathrm{O}_{3}$ (JCPDS, 24-554), and to 
metalloclusters $\mathrm{Al}_{3} \mathrm{La}$ (JCPDS, 19-25), $\mathrm{AlCe}_{3}$ (JCPDS, 9-269), and $\mathrm{AlLa}_{3}$ (JCPDS, 25-1131).

TABLE II: THE TEXTURAL CHARACTERISTICS OF CATALYSTS

\begin{tabular}{lllll}
\hline \hline Catalysts & $\mathrm{T},{ }^{\circ} \mathrm{C}$ & $\begin{array}{c}\text { Surface } \\
\text { Area } \\
/\left(\mathrm{m}^{2} / \mathrm{g}\right)\end{array}$ & $\begin{array}{l}\text { Pore } \\
\text { volume } \\
/\left(\mathrm{cm}^{3} / \mathrm{g}\right)\end{array}$ & $\begin{array}{l}\text { Average } \\
\text { pore size } \\
/ \mathrm{nm}\end{array}$ \\
\hline$\gamma \mathrm{Al}_{2} \mathrm{O}_{3}$ & - & 171 & 0.084 & 1.98 \\
$\mathrm{Ce} / \mathrm{Al}_{2} \mathrm{O}_{3}$ & 200 & 162 & 0.070 & 1.71 \\
$\mathrm{Ce} / \mathrm{Al}_{2} \mathrm{O}_{3}$ & 300 & 133 & 0.088 & 2.64 \\
$\mathrm{Ce} / \mathrm{Al}_{2} \mathrm{O}_{3}$ & 400 & 69 & 0.045 & 2.58 \\
$\mathrm{Ce} / \mathrm{Al}_{2} \mathrm{O}_{3}$ & 500 & 133 & 0.079 & 2.36 \\
$4 \% \mathrm{CeLa} / \mathrm{Al}_{2} \mathrm{O}_{3}$ & 500 & 162 & 0.069 & 1.71 \\
$5 \% \mathrm{CeLa} / \mathrm{Al}_{2} \mathrm{O}_{3}$ & 500 & 173 & 0.074 & 1.72 \\
$6 \% \mathrm{CeLa} / \mathrm{Al}_{2} \mathrm{O}_{3}$ & 500 & 174 & 0.075 & 1.72 \\
\hline \hline
\end{tabular}

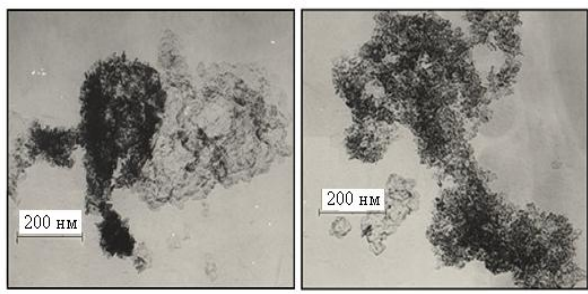

Fig. 7. Microphotos of $\mathrm{Ce} / \gamma-\mathrm{Al}_{2} \mathrm{O}_{3}$ sample.
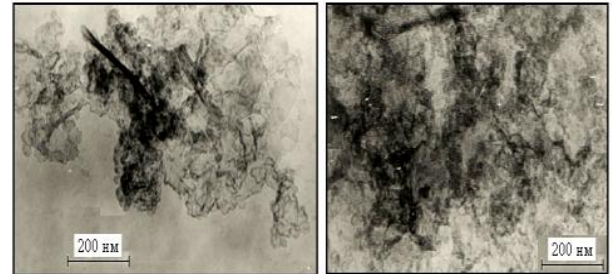

Fig. 8. Microphotos of $\mathrm{CeLa} / \gamma-\mathrm{Al}_{2} \mathrm{O}_{3}$ sample.

The formation of acid sites on the surface of the cerium-containing catalysts was studied via the temperature-programmed desorption of ammonia. The desorption of ammonia from the surface of the $\mathrm{Ce} / \gamma-\mathrm{Al}_{2} \mathrm{O}_{3}$ catalyst (Table III) proceeds within three ranges of temperature with maxima at 160,480 , and $670^{\circ} \mathrm{C}$.

TABLE III: RESULTS OF THE TEMPERATURE -PROGRAMMED DESORPTION OF AMMONIA FROM CATALYSTS ( $V$ IS THE AMOUNT OF ADSORBED AMMONIA)

\begin{tabular}{lccc} 
Catalysts & $\mathrm{T}$ max, ${ }^{\circ} \mathrm{C}$ & $V, \mathrm{~mL} /(\mathrm{g}$ cat & $\begin{array}{c}V \times 10-4, \\
\mathrm{~mol} /(\mathrm{g} \text { cat })\end{array}$ \\
\hline & 160 & 20.88 & 9.32 \\
$\mathrm{Ce} / \gamma-\mathrm{Al}_{2} \mathrm{O}_{3}$ & 480 & 16.16 & 7.21 \\
& 670 & 13.52 & 6.04 \\
$\mathrm{Ce} \mathrm{La}$ & 145 & 27.52 & 12.29 \\
$/ \gamma-\mathrm{Al}_{2} \mathrm{O}_{3}$ & 470 & 11.92 & 5.3 \\
\hline \hline
\end{tabular}

Within the temperature range of $50-365^{\circ} \mathrm{C}$, ammonia was apparently desorbed from the weak acid sites of the catalyst in the amount of $9.32 \times 10^{-4} \mathrm{~mol} /(\mathrm{g}$ cat $)$. Ammonia was desorbed from medium strength sites in the range of $365-580^{\circ} \mathrm{C}$ and from strong acid sites in the range of $580-890^{\circ} \mathrm{C}$ in amounts of $7.21 \times 10^{-4}$ and $6.04 \times 10^{-4} \mathrm{~mol} /(\mathrm{g}$ cat)), respectively [12]. After doping the cerium catalyst with lanthanum, ammonia was also desorbed in three ranges of temperature with maxima at 145,470 , and $660^{\circ} \mathrm{C}$. The amount of ammonia desorbed from weak acid sites grew from $9.32 \times 10^{-4}$ to $1.229 \times 10^{-3} \mathrm{~mol} /(\mathrm{g}$ cat $)$,compared to $\mathrm{Ce} / \gamma-\mathrm{Al}_{2} \mathrm{O}_{3}$ catalyst. The amount of ammonia desorbed from medium strength and strong acid sites fell from $7.21 \times 10^{-4}$ to $5.3 \times 10^{-4} \mathrm{~mol} /(\mathrm{g}$ cat$)$, and from $6.04 \times 10^{-4}$ to $5.79 \times 10^{-4}$ $\mathrm{mol} /$ (g cat), respectively.

\section{CONCLUSION}

Thus the study of conversion of bioethanol 1 and bioethanol 2 over zeolites allows to identify the products of dehydratation of alcohol - ethylene, cracking - methane, reforming - hydrogen and carbon monoxide. Also aromatic hydrocarbons - toluene, benzene, which are the next products of ethylene oligomerization. Formation of toluene at conversion of industrial alcohol may also depends on the presence of additives tert-butilcarbinol, cyclohexane, and others in the composition of alcohol. The explanation of this will be the subject of our following research works.

The of conversion bioethanol 1 over Ce-containing catalysts showed that the synthesized catalysts exhibited high activity and productivity in the catalytic conversion of bioethanol 1 . The highest activity was observed on the $\mathrm{CeLa} / \gamma-\mathrm{Al}_{2} \mathrm{O}_{3}$ catalyst. At the optimum process parameters (reaction temperature, $400^{\circ} \mathrm{C}$; HSV, $6000 \mathrm{~h}^{-1}$; ethanol concentration, $19.7 \mathrm{~g} / \mathrm{m}^{3}$ ), the yield of ethylene reached 82 vol. $\%$ at an ethanol conversion of $94 \%$ with a selectivity of $87.2 \%$. Electron microscopy showed that doping $\mathrm{Ce} / \gamma-\mathrm{Al}_{2} \mathrm{O}_{3}$ with lanthanum increases its dispersion, and some aggregates of fine $(2 \mathrm{~nm})$ particles could be observed. Temperature-programmed desorption revealed that doping $\mathrm{Ce} / \gamma-\mathrm{Al}_{2} \mathrm{O}_{3}$ catalyst with lanthanum raised the total number of acid sites from $2.257 \times 10^{-4}$ to $2.338 \times 10^{-3} \mathrm{~mol} /(\mathrm{g}$ cat $)$.

According to data from electron microscopy and the temperature-programmed desorption of ammonia, the high activity of the $\mathrm{CeLa} / \gamma-\mathrm{Al}_{2} \mathrm{O}_{3}$ catalyst was apparently due to an increase in its dispersion and the number of acid sites, relative to $\mathrm{Ce} / \gamma-\mathrm{Al}_{2} \mathrm{O}_{3}$ catalyst.

\section{REFERENCES}

[1] L. Yu. Dolgikh, Y. I. Pyatnitskii, S. I. Reshetnikov, and I. V. Deinega, "Effect of crystalline modification of the support on the reduction and catalytic in the steam reforming of bioethanol," Theoretical and Experimental Chemistry, vol. 47, pp. 324-330, 2011.

[2] M. Kunz, "Bioethanol: Experiences from running plants, optimization and prospects," Biocatalysis and Biotransformation, vol. 26, pp. 128-132, 2008.

[3] L. Siwale, A. Kolesnikov, and L. Kristof, "Combustion and emission characteristics of n-butanol, Diesel fuel blend in a turbo-charged compression ignition engine," Fuel, vol. 107, pp. 409-418, 2013.

[4] V. F. Tretyakov, A. S. Lermontov, Y. I. Makarfi, and M. S. Yakimova, "Synthesis of motor fuels from bioethanol," Chemistry and Technology of Fuels and Oils, vol. 44, no. 6, pp. 409-414. 2008.

[5] N. Bukhanko, A. Samikannu, and W. Larsson, "Continuous gas-phase synthesis of 1-ethyl chloride from ethyl alcohol and hydrochloric acid over $\mathrm{Al}_{2} \mathrm{O}_{3}$-based catalysts: The "Green" route," ACS Sustainable Chemistry and Engineering, vol. 1, no. 8, pp. 883-893, 2013.

[6] I. K. Kapdan and F. Kargi, "Bio-hydrogen production from waste materials," Enzyme Microb. Technol, vol. 38, pp. 569-582. 2006.

[7] A. Faur Ghenciu, "Review of fuel processing catalysts for hydrogen production in PEM fuel cell systems," Curr. Opin. Solid State Mater. Sci., vol. 6, pp. 389-399, 2002.

[8] N. Laosiripojana and S. J. Assabumrungrat, "Catalytic steam reforming of methane, methanol, and ethanol over Ni/YSZ: The 
possible use of these fuels in internal reforming SOFC," Power Sources, vol. 163, pp. 943-951, 2007.

[9] R. Vasant, Choudhary, and K. C. Mondal, " $\mathrm{CO}_{2}$ reforming of methane combined with steam reforming or partial oxidation of methane to syngas over $\mathrm{NdCoO}_{3}$ perovskite-type mixed metal-oxide catalyst," Applied Energy, vol. 83, pp. 1024-1032, 2006.

[10] T. Benjamin Schädel, M. Duisberg, and O. Deutschmann, "Steam reforming of methane, ethane, propane, butane, and natural gas over a rhodium-based catalyst," Catal. Today, vol. 142, pp. 42-51, 2009.

[11] N. V. Parizotto, K. O. Rocha, and S. Damyanova et al., "Alumina-supported $\mathrm{Ni}$ catalysts modified with silver for the steam reforming of methane: Effect of $\mathrm{Ag}$ on the control of coke formation," Appl. Catal. A: Gen. vol. 330, pp. 12-22, 2007.

[12] News-Bioethanol. [Online]. http://www.biotoplovo.rulhtml/news-bioethanol_1.html

[13] A. Caravaca, A. De Lucas-Consuegra, A. B. Calcerrada, J. Lobato, J. L. Valverde, and F. Dorado, "From biomass to pure hydrogen: electrochemical reforming of bio-ethanol in a PEM electrolyser,' Applied Catalysis B: Environmental, vol. 134-135, pp. 302-309, 2013.

[14] R. Kanaparthi, L. Mei Hui, H. Yi-Fan, and A. Borgna, "Structure and reactivity of ethanol dehydration," Catalysis Communications, vol. 10, no. 5, pp. 567-571, 2009.

[15] P. Yeletsky, Y. Larichev, and K. Iost et al., "Development of progress of high- ash biomass conversion into carbonoceous catalyst supports. Adsorbents and materials for super capacitors," in Proc. XX Intern. Conf. on Chemical Reactors CHEMREACTOR-20, Luxemburg, December 3-7, 2012.

[16] M. R. Westa, L. E. Kunkesa, and A. Dante, "Catalytic conversion of biomass-derived hydrocarbon intermediates," Catalysis Today, vol. 147 , no. 2, pp. 115-125, 2009.

[17] V. V. Yuchenko, "Calculation of the spectra of acidity the catalysts according to the data TPD," Journal of Physical Chemistry, vol. 71, no. 4, pp. 628-632, 1997.

[18] O. S. Marina, D. Marcelo, and P. da Cunha et al., "Simulation of integrated first and second generation bioethanol production from sugarcane: Comparison between different biomass pretreatment methods," J Ind Microbiol Biotechnol, vol. 38, pp. 955-966, 2011.

[19] S. Rapagná, H. Provendier, C. Petit, A. Kiennemann, and P. U. Foscolo, "Development of biomass gasification," Biomass Bioenergy, vol. 22, pp. 377-388, 2002

[20] I. K. Kapdan and F. Kargi, "Bio-hydrogen production from waste materials," Enzyme Microb. Technol, vol. 38, pp. 569-582, 2006.

[21] S. Rapagná, H. Provendier, C. Petit, A. Kiennemann, and P. U. Foscolo, "Development of biomass gasification," Biomass Bioenergy, vol. 22, pp. 377- 388, 2002.

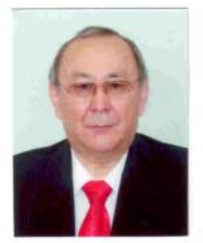

Dossumov Kusman was born in Semipalatinsk, Republic of Kazakstan on February 27, 1950. In 2000, he got professor degree, chemistry, Almaty, Kazakhstan. In 1996, he got doctor degree diploma, catalysis, IOCE AS RK, Almaty, Kazakhstan. In 1981, he got his candidate degree diploma, IOCE AS RK, Almaty, Moscow, SU. In 1972, he got the high education diploma Kaz SU, chemistry, Almaty,
Kazakhstan. He is the deputy director of CHMA al-Farabi Kaz NU, Almaty, Kazakhstan since 2011. He was the general director of D.V.Sokolsky Institute of Organic Catalysis \& Electrochemistry (IOCE) Ministry of Education \& Science (MES) Republic of Kazakstan (RK) from 2007 to 2010. From 1995 to 2007, he was the deputy director of D.V.Sokolsky IOCE MES RK. From 1972 to 1995 , he is a leading science researcher, senior science researcher, junior science researcher, engineer of IOCE NAS RK. His current and previous research interests are catalysis, petrochemistry, ecology.

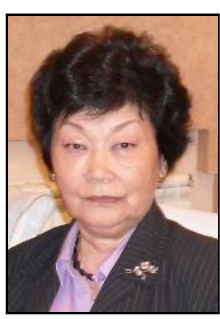

Churina Dina Khamidovna was born in Alma-Ata in November 17, 1943. In 1985, she got leading researcher diploma, Moscow, SU. In 1973, she got diploma of candidate of chemical science, catalysis, electrochemistry, Almaty, Kazakhstan. In 1965, she got high education diploma Kaz SU, chemistry, catalysis, Almaty, Kazakhstan. 2011-current, she is a Senior researcher CHMA al-Farabi Kaz NU, Almaty, Kazakhstan. 1978-2010, she was a secretary of scientific affairs IOCE NAS RK, Almaty, Kazakhstan. 1965-1978, she was a science researcher, an engineer of IOCE AS RK, Almaty, Kazakhstan. Her current and previous research interests are catalysis, electrochemistry, ecology.

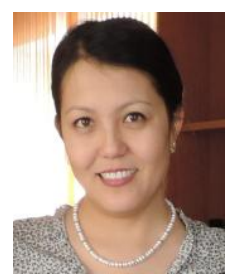

Yergaziyeva Gaukhar Yergaziyevna was born in Alma-Ata on September 27, 1979. In 2011, she got diploma of candidate of chemical science, catalysis, Almaty, Kazakhstan. In 2002, she got diploma of master KazNU al-Farabi, Almaty, Kazakhstan. In 2000, she got diploma of bachelor KazNU al-Farabi, Almaty, Kazakhstan. In 2013, she was a leading science researcher of Institute of Combustion Problems. 2003-2011, she was a senior science researcher, junior science researcher, and an engineer of IOCE NAS RK. Her current and previous research interests are catalysis, petrochemistry, ecology.

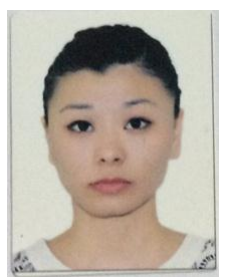

Telbayeva Moldir Muratbekovna was born in Almaty, Republic of Kazakhstan on January 7, 1988. In 2012, she got diploma of master course at al-Farabi Kaz NU, Almaty, Kazakhstan. She is a junior researcher in Institute of Combustion Problems, Almaty, Kazakhstan since 2011. From 2009 to 2011, she was an engineer of IOCE NAS RK, Almaty, Kazakhstan. Her current and previous research interests are catalysis, ecology. 